\title{
William F. King.
}

By the recent death at Hunter's Quay of Mr William F. King there passes one of the now few remaining pioneers in submarine cable telegraphy work and in manufacturing electrical engineering.

At an early age Mr King studied for some years in the Science Department at Glasgow University under the late Sir William Thomson (Lord Kelvin), where his high electrical and mathematical abilities were so prominent that he was sent in May 1869 by Sir William Thomson to Sir James Anderson in London, to whom Lord Kelvin introduced him as "King, a young Faraday from Glasgow." There Mr King demonstrated Sir William Thomson's new mirror-reflecting galvanometer, and in the following month he was appointed to the engineering staff of the French Trans-Atlantic Cable Company, and sailed in the Great Eastern for St Pierre, Newfoundland. At the Atlantic Cable Station there he established the new Thomson mirror-reflecting galvanometer, which increased the speed of messages from about one or two words per minute by the Morse system to fifteen or more words per minute-thereby, in a large measure, ensuring the commercial success of submarine cable working.

In 1870 Sir William Thomson's early and improved form of Siphon Recorder was installed there by Mr King, marking a further great advance in submarine telegraphy; and the very able manner in which all these early experiments were conducted and successfully carried through led to $\mathrm{Mr}$ King's appointment in 1873 to the post of Chief Engineer to the Western and Brazilian Telegraph Company, under whom he was responsible for laying and establishing the first submarine cable for Brazil. For these eminent services he was appointed in 1874 a Knight of the "Order of the Rose" by the late Emperor, Dom Pedro II.

After a further ten years' work in the development of submarine telegraphy on various Atlantic cables, Mr King returned to Scotland and, along with the late $\mathrm{Mr}$ Andrew Betts Brown, hydraulic engineer, he formed in 1884 the firm of King, Brown \& Co., manufacturing electrical engineers, at Rosebank Electric Works, Edinburgh.

$\mathrm{He}$ then applied himself to the design and manufacture there of various types of dynamos, submarine cable-laying machines, electric lamps, motors, etc.; and it is interesting to note that the entire lighting of the first Exhibition in Edinburgh in 1886 was carried out by 
him from ten of these early "300-light" dynamos manufactured at his works at Rosebank.

In 1888 his firm contested the claim of the Anglo-American Brush Electric Light Corporation, Ltd., to their sole rights for the compound winding of dynamos, which was ultimately confirmed in his firm's favour by the House of Lords' decision in 1891. Thus he was primarily instrumental in liberating for all manufacturers of dynamos the use of compound winding, whereby a great stimulus was secured to the British electrical industry.

In 1894, on the dissolution of his partnership with the late Mr Betts Brown, Mr King removed his business to Leith Electric Works, Leith, under the title of King \& Company, where, with two young partners, he continued his work in the manufacture and installation of all classes of electrical machinery for lighting and power purposes. During the whole period of the war the works and staff at Leith were wholly absorbed by the Admiralty for the execution of all repairs and maintenance services on H.M. vessels at Rosyth and Leith, and on the conclusion of the war the Admiralty conveyed their thanks to the firm for the valuable services rendered through these strenuous years.

In recent years $\mathrm{Mr}$ King devoted much of his leisure to the practical development of scientific refinements in clocks. He devised and constructed with his own hands a very beautiful chronometer escapement adapted for a pendulum, by which a very heavy pendulum was operated with an exceedingly light impulse. The clock he made, which comprises numerous details of interest, is now at the Royal Observatory, Edinburgh. In all this work his exceptional mechanical craftsmanship in the delicate details was ably evidenced.

For the last few years he has resided at Hunter's Quay, Argyllshire, with which he has been associated for over fifty years, and where, as an old member of all the Yacht Clubs, he was well known as a keen yachtsman.

He was elected a Fellow of the Society in 1880, and died on 6th October 1929.

A. 0 . 